\title{
Standardization of Tinting Techniques in China aster cv. Local White
}

\author{
P. Ranchana*, M. Ganga, M. Jawaharlal and M. Kannan \\ Department of Floriculture and Landscaping, HC \& RI, TNAU, Coimbatore- 3, \\ Tamil Nadu, India \\ *Corresponding author
}

\section{A B S T R A C T}

\section{Keywords \\ Value addition, \\ Tinting, China aster, Novel colours.}

Article Info

Accepted:

04 July 2017

Available Online:

10 September 2017
Value addition in floriculture increases the economic value and consumer appeal of any floral commodity. The profitability of a commodity is increased when the raw material is converted into a value added product which can directly or indirectly influence floral market to a great extent. An experiment was conducted to standardize the tinting technologies in China aster var. Local white. In this study, the food dyes viz., Apple Green, Lemon Yellow and Orange Red were used in three different concentrations including control. Tinting was done by stem absorption method (Sambandhamurthy and Appavu, 1980). Tinted flowers @ 4\% concentration expressed full bright coloured flowers in the inflorescence with quick uptake of colours in a short period of two hours duration. But, the vase life (one day) and water uptake $(0.8,1.6$ and $1 \mathrm{ml})$ was recorded minimum in all the tinted flowers@ @ $\%$ concentrations. By using the tinted flowers, flower arrangements can be made which will be of very novel and attractive. Value addition ensures high premium price to the China aster grower.

\section{Introduction}

China aster is an important annual flower crop and is widely loved due to their spectacular blooms in single, double or semi double forms in various colours. The success of flora industry is ultimately dependent upon the efficiency of strengthening the fresh flower market through value addition (Mekala et al., 2012). Flower trade is one of the most rapidly expanding and dynamic enterprises in today's world. In this trade, value addition and postharvest handling methods of cut flowers is a fascinating and gratifying industry gaining importance now-a-days.

Tinting is an important value addition technique in flower crops where colour pigments are absent or light or dull. Tinting can be done with natural and artificial flowers. It enhances the aesthetic beauty of fresh and dry flowers. Colouring inflorescences with edible dyes enhance the visual appeal of these flowers and increase their economic value. It can also provide a great variety of colours for aesthetic beautification. For decorative purpose where a particular colour is desired, tinting of white flower is an easy way of obtaining the colour of interest. Whereas, certified synthetic food colours are less expensive, less hazardous and don't impart an intense and uniform colour to the tinted flowers. Tinting techniques has already been experimented in tuberose (Sambandhamurthy and Appavu, 1980; Kumar et al., 2004; Mekala et al., 2012 and 
Yamini, 2016), Lady's Lace (Patil and Dhakuk, 2008), Candytuft (Patil and Dhakuk, 2005) and white flowered cultivars of gladiolus (Sravan Kumar et al., 2014). This technique can serve as a potential tool for white coloured China aster flower to achieve varied colours.

\section{Materials and Methods}

The present study on "Standardization of tinting techniques in China aster cv. Local White" was carried out at the Department of Floriculture and Landscaping, Tamil Nadu Agricultural University, Coimbatore during the year 2016-17. China aster is an important cut flower widely used in bouquet and also in many flower arrangements. A white coloured variety Local White is used in this study. This study was conducted by using food dye solutions viz., Apple Green, Lemon Yellow and Orange Red each at three different concentrations $(2 \%, 3 \%$ and $4 \%)$ including control. This experiment was conducted in completely randomized design with 10 treatments and each replicated thrice.

Artificial colouration of flowers (tinting) can be done in two ways viz, through the stem absorption method (for carnation, tuberose, gerbera) and by dipping of flower heads (for other flowers, principally daisies). Mostly the colour retention will be good in flowers tinted through stem. Application of the dyes through the stem absorption method will be optimum method for colouring of tuberose flowers (Sambandhamurthy and Appavu, 1980). In this study, tinting was done by stem absorption method (Sambandhamurthy and Appavu, 1980). Fresh flower of China aster was tinted by keeping the basal ends dipped in the dye solution. The time of immersion of cut spikes was standardized by observing the improved colour intensity in the florets. After this, flowers were taken out from the dye solution and placed in the distilled water for recording the parameters viz., colour uptake and intensity, water uptake and vase life. Colour intensity was recorded by RHS colour chart (Sravan Kumar et al., 2014). Vase life was recorded by placing the tinted cut stems in distilled water. The data on all qualitative and quantitative parameters were subjected to statistical analysis as per the procedure outlined by Panse and Sukhatme (1985). The results have been presented and discussed at a probability level of 0.05 or 5 percent probability.

\section{Results and Discussion}

In the present study, the food dyes viz., Apple Green, Lemon Yellow and Orange Red recorded the fastest uptake requiring only 2.1, 2.4 and 2.3 hours with excellent final colour (Fig. 1 and Table 1). Colour intensity was recorded using RHS colour chart by assigning different codes for flower colour as reported by Sravan Kumar et al., 2014 and Yamini, 2016. With increase in concentration of dye an increase in intensity of the colour in the flower petals was observed.

However, higher concentrations were generally associated with reduced vase life in case of the tinted spikes (Table 2). Colour intensity was found to be best by using food dyes at higher concentration (4\%) when compared to other treatments. This is in agreement with the result of Yamini (2016) and Safeena et al., (2016) in tuberose.

The water uptake of all tinted and normal inflorescence of China aster was calculated on next day after tinting. The results showed that the tinted inflorescence was noticed with reduced water uptake. Whereas, untreated inflorescence (control) was found with higher water uptake. Therefore, higher vase life (7.27 days) was resulted in the control inflorescence which showed increased water uptake (5.4 $\mathrm{ml})$. 
Fig.1 Colour intensity of tinted China aster var. Local White

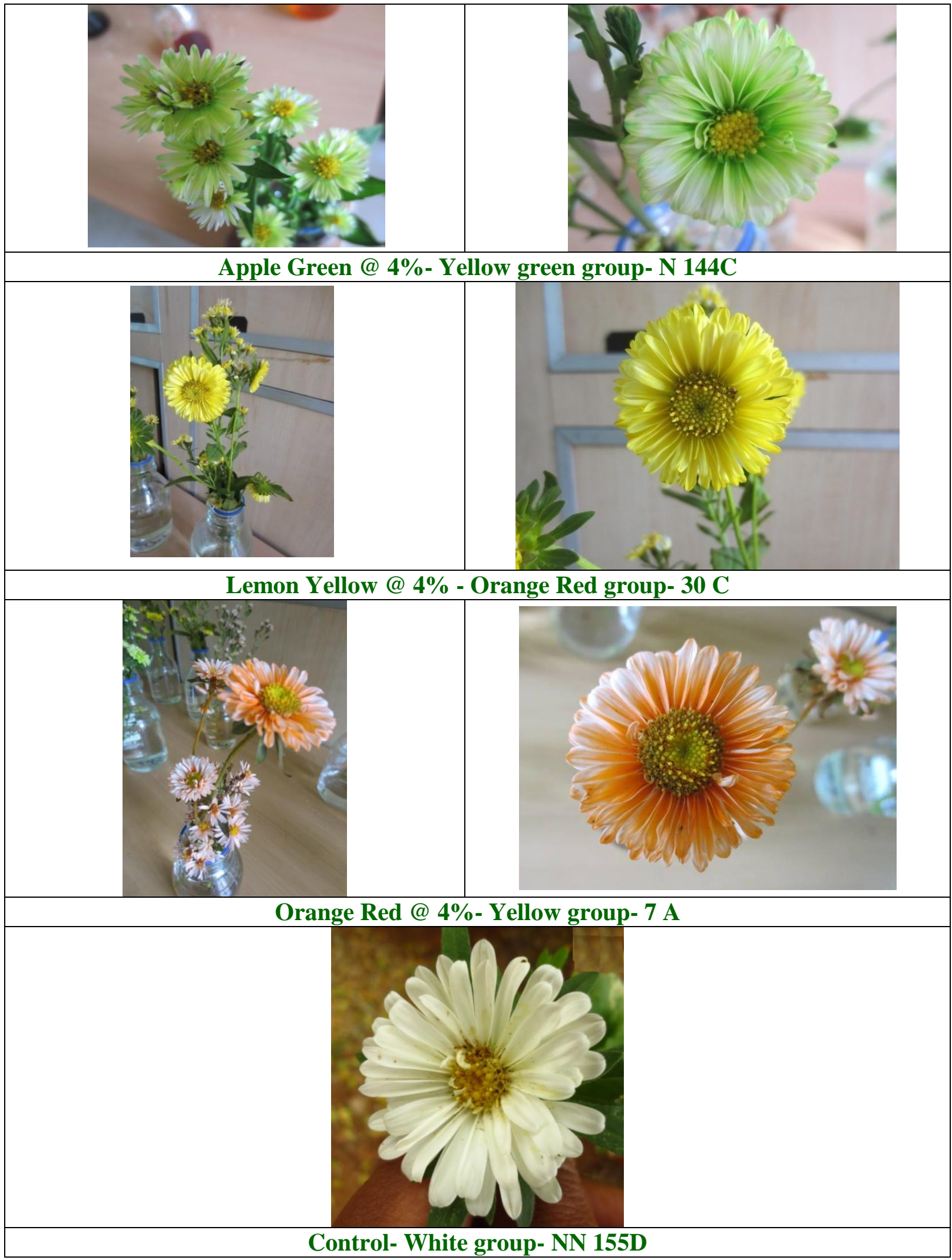


Table.1 Effect of different tinting treatments on colour intensity and colour uptake of China aster cv. Local White flowers

\begin{tabular}{|c|c|c|c|}
\hline \multirow[t]{2}{*}{ Treatments } & \multicolumn{2}{|c|}{$\begin{array}{c}\text { Colour intensity } \\
\text { (RHS colour chart) }\end{array}$} & \multirow{2}{*}{$\begin{array}{l}\text { Colour } \\
\text { uptake } \\
\text { (Hours) }\end{array}$} \\
\hline & \begin{tabular}{|l|} 
Colour group \\
\end{tabular} & Colour code & \\
\hline Apple Green @ 2\% & Green group & $142 \mathrm{~A}$ & 4.3 \\
\hline Apple Green @ 3\% & Yellow green group & N 144B & 3.2 \\
\hline Apple Green @ 4\% & Yellow green group & N 144C & 2.1 \\
\hline Lemon Yellow @ 2\% & Orange Red group & $30 \mathrm{C}$ & 4.2 \\
\hline Lemon Yellow@3\% & Orange Red group & $30 \mathrm{~B}$ & 3.5 \\
\hline Lemon Yellow @ 4\% & Orange Red group & $30 \mathrm{~A}$ & 2.4 \\
\hline Orange Red @ 2\% & Yellow group & $2 \mathrm{~B}$ & 4.5 \\
\hline Orange Red @ 3\% & Yellow group & $6 \mathrm{~A}$ & 3.8 \\
\hline Orange Red @ 4\% & Yellow group & $7 \mathrm{~A}$ & 2.3 \\
\hline Control & White group & NN 155D & - \\
\hline \multicolumn{3}{|c|}{\begin{tabular}{l|ll} 
& Mean \\
\end{tabular}} & 3.03 \\
\hline \multicolumn{3}{|r|}{ SE(D) } & 0.12 \\
\hline \multicolumn{3}{|r|}{$\mathrm{CD}(5 \%)$} & 0.25 \\
\hline
\end{tabular}

Table.2 Effect of different tinting treatments on water uptake and vase life of China aster cv. Local White flowers

\begin{tabular}{|r|c|c|}
\hline \multicolumn{1}{|c|}{ Treatments } & Water uptake on first day of tinting (ml) & Vase life(days) \\
\hline Apple Green @ 2\% & 1.1 & 1.3 \\
\hline Apple Green @ 3\% & 0.9 & 1.1 \\
\hline Apple Green @ 4\% & 0.8 & 1.0 \\
\hline Lemon Yellow @ 2\% & 3.0 & 1.6 \\
\hline Lemon Yellow @ 3\% & 1.9 & 1.2 \\
\hline Lemon Yellow @ 4\% & 1.6 & 1.0 \\
\hline Orange Red @ 2\% & 4.5 & 1.5 \\
\hline Orange Red @ 3\% & 2.7 & 1.2 \\
\hline Orange Red @ 4\% & 1.0 & 1.0 \\
\hline Control & 5.4 & 7.27 \\
\hline Mean & 2.29 & 1.81 \\
\hline SE(D) & 0.04 & 0.05 \\
\hline CD (5\%) & 0.09 & 0.12 \\
\hline
\end{tabular}

But the flowers tinted by using food colours viz., Apple Green, Lemon Yellow and Orange Red with higher concentration @ 4\% showed minimum water uptake of $0.8,1.6$ and $1 \mathrm{ml}$ which leads to minimum vase life (1 day). This result is in consonance with the findings of Yamini, 2016 and Safeena et al., 2016 in tuberose.
Vase life of tinted inflorescence of China aster was recorded by placing the cut stems in distilled water (Table 2). China aster inflorescence tinted with Apple Green, Lemon Yellow and Orange Red at 2\% recorded higher vase life $(4.3 ; 4.2 ; 4.5$ days). Whereas, untreated inflorescence (control) registered maximum vase life (7.27 days). It 
was found that higher the concentration of dyes, lower the vase life of tinted flowers. This is in line with the findings of Yamini, (2016) and Safeena et al., (2016) in tuberose. The flowers remained fresh for one day after tinting and it showed the sign of wilting on second day and completely wilted on third day which varies with the concentrations of food dyes used in all the tinted inflorescence.

The result of this experiment showed that the tinted flowers will be very attractive and of good appeal which holds excellence in the flower arrangements. But at the same time, it possesses less vase life. Hence, tinted flowers will be used to display for one day only.

\section{References}

Kumar Vinod, and Bhattacharjee, S.K., 2004. Influence on colouring agents on postharvest life and quality of tuberose spikes. Scientific Horticulture. 9: 187191.

Mekala, P., Ganga, M, and Jawaharlal, M. (2012). Artificial colouring of tuberose flowers for value addition. South Indian Horticulture. 60: 216-223.

Panse, V.G., Sukhatme, P.V. Statistical Methods for Agricultural Workers, ICAR, New Delhi, 4th edition, 1985, 347.

Patil, S.D., and Dhakuk, B.K. 2008. Value addition of Lady's Lace (Pimpinella monoica) cut flowers by colouring with edible dyes. Journal of Ornamental Horticulture. 11(1):32-36.
Patil, S.D., and Dhakuk, B.K. 2005. Value addition of Candytuft (Iberis umbellate L.) cut flowers by colouring with edible dyes. In: National Seminar on Crop Productivity and Quality Improvements Through Physiological Interventions, Navsari, Gujarat, pp 23-25.

Safeena, S. A., Thangam, M. and Singh, N. P. 2016. Value addition of tuberose (Polianthes tuberosa 1.) spikes by tinting with different edible dyes. Asian Journal of Research in Biological and Pharmaceutical Sciences. 4(3): 89 - 98.

Sambandhamurthy, S., and Appavu, K. 1980. Effect of the chemical on colouring of tuberose (Polianthes tuberosa L.). Proc. of National Seminar on Production Technology for Commercial Flower Crops, TNAU, Coimbatore, Tamil Nadu, India, pp 73-75.

Sravan Kumar, B., Lalitha Kameswari, P., Pratap, M. and Venkateswar Rao, P. 2014. Optimization of stage of harvest of spikes of gladiolus cultivar White prosperity for tinting. Agric. Sci. Digest., 35(2): 89-94.

Yamini, R., 2016. Standardization of tinting techniques for tuberose (Polianthes tuberosa L.) and orchid (Dendrobium spp.) flowers. M.Sc. thesis submitted at the Department of Floriculture and Landscaping, Tamil Nadu Agricultural University, Coimbatore.

\section{How to cite this article:}

Ranchana, P., M. Ganga, M. Jawaharlal and Kannan, M. 2017. Standardization of Tinting Techniques in China aster cv. Local White. Int.J.Curr.Microbiol.App.Sci. 6(9): 27-31. doi: https://doi.org/10.20546/ijcmas.2017.609.003 